\title{
PENGARUH BUDAYA DAN NILAI ISLAM: Terbentuknya Arsitektur Vernakular Minangkabau
}

\author{
Ernaning Setiyowati \\ Jurusan Teknik Arsitektur Fakultas Sains dan Teknologi Universitas Islam Negeri Malang Telp. \\ 08155552680 e-mail: ninkarch99@yahoo.com
}

Abstract

Vernacular Architecture was called as populace architecture that formed because pattern of life, social, culture, and religious from certain society. This thing was caused program of vernacular architecture different in every place. All of vernacular architecture have special characteristic. Also, there is vernacular architecture of Minangkabau. Vernacular architecture of Minangkabau often called as large sprawling house. The uniqueness of that society is specially in matrilineal culture, bringing to one design of living house which different to general modern house. The space formation is based on women life and having hierarchy appropriate with sickles of women life. Type of buildings totality having uniqueness because historical factor and legend. Even, name of building is large sprawling house also having content of historical value and legend. The element of local material also support this uniqueness. Because local material that used in large sprawling house is not truly used in others region. Aspects of social and local culture that arrange the forms of vernacular architecture of Minangkabau. It is not free from Islamic values moreover supports an Islamic values in some designed aspect.

Key words: vernacular architecture, minangkabau, and large sprawling house 


\section{Pendahuluan}

Arsitektur vernakular bisa dikatakan sebagai arsitektur rakyat, yaitu arsitektur yang merupakan hasil dari sebuah kultur vernakular dan komunitas masyarakat tertentu (civilization). Arsitektur vernakular memiliki sifat turuntemurun hingga beberapa generasi. Pembangunannya berdasar kepada pengetahuan tentang teknik dan pengalaman tradisional; biasanya dibangun sendiri (kemungkinan dibantu oleh keluarga, kerabat, atau tukang dalam sukunya) (Prijotomo, 2004: 61). Meskipun dibangun sendiri, bangunan vernakular tetap memiliki kualitas yang baik.

Struktur bangunan vernakular mudah dipelajari dan dimengerti. Terbuat dari material lokal. Cocok secara ekologi, yaitu sesuai dengan iklim lokal, flora, fauna dan pola kehidupan. Dengan demikian, bangunan vernakular memiliki kesesuaian dengan lingkungan dan memiliki skala manusia. Proses membangun lebih penting daripada hasil akhir produk. Kombinasi dari ketepatan yang baik secara ekologi, skala manusia, memperjuangkan kualitas, bersamaan dengan perhatian yang kuat untuk dekorasi, ornamentasi dan penghiasan, membawa kepada sensasi kesederhanaan yang menghasilkan kemewahan yang sesungguhnya (Papanek, 1995: 26). Nilai-nilai kelokalan dari arsitektur vernakular tersebut juga sesuai dengan nilai-nilai Islam.

Secara umum berdirinya arsitektur vernakular dipengaruhi oleh beberapa faktor, antara lain:

1. Ketersediaan material

2. Jenis iklim dan keadaan lingkungan sekitar

3. Tapak dan topografi

4. Kemampuan ekonomi

5. Penguasaan teknologi

6. Kebutuhan hidup sehari-hari

7. Simbolisme \& makna

8. Kebiasaan dan tradisi

9. Kultural, sosial, dan kosmologi

10. Religi dan ritual

11. Keamanan

12. Gender dan posisi wanita

Berbagai macam aspek di atas memiliki pengaruh yang berbeda-beda terhadap arsitektur vernakular di lokasi yang berlainan. Bahkan ada beberapa aspek di atas yang tidak berpengaruh sama sekali terhadap arsitekturnya. 
Salah satu negara yang memiliki banyak arsitektur vernakular yang beragam adalah Indonesia. Hampir setiap daerah di Indonesia memiliki arsitektur tradisional yang berbeda-beda. Semuanya memiliki arsitektur yang berciri khas yang berbeda-beda yang dipengaruhi oleh berbagai aspek-aspek yang disebut di atas. Salah satu daerah itu adalah Sumatra Barat yang masyarakatnya disebut dengan masyarakat Minangkabau.

Masyarakat Minangkabau memiliki arsitektur tradisional yang dikenal dengan nama rumah Gadang (rumah Besar/rumah Buranjang). Dikatakan Gadang (besar) bukan karena fisiknya yang besar melainkan karena fungsinya selain sebagai tempat kediaman keluarga, rumah Gadang merupakan perlambang kehadiran satu kaum dalam satu nagari, serta sebagai pusat kehidupan dan kerukunan seperti tempat bermufakat keluarga kaum dan melaksanakan upacara. Bahkan sebagai tempat merawat anggota keluarga yang sakit (Syamsidar, 1991: 56). Terbentuknya rumah Gadang tersebut beserta perkampungannya dipengaruhi oleh berbagai aspek seperti yang mempengaruhi terbentuknya arsitektur vernakular pada umumnya.

\section{Pengaruh Aspek Sejarah pada Arsitektur}

Menurut yang tertulis di dalam Tambo Alam (buku sejarah kelahiran Minangkabau), nenek moyang Minangkabau berasal dari Indocina yang bermigrasi ke selatan beberapa ribu tahun yang lalu, berpindah dengan menggunakan kapal sampai ke Selat Malaka. Dari selat itu mereka berjalan ke barat menuju ke Gunung Marapi, dan akhirnya menetap di dataran kaya yang subur di tengah dataran Sumatra di dasar Gunung Marapi. Tepatnya adalah di daerah Pariangan Padang Panjang, yaitu sebuah Nagari yang terletak di sebelah barat Gunung Marapi. Di sinilah awal mula terbentuknya permukiman Minangkabau (Syamsidar, 1991: 59).

Karena Gunung Marapi merupakan tempat asal mula budaya Minangkabau berkembang, maka dipercaya bahwa Gunung Marapi inilah yang memberi penghidupan bagi masyarakat Minangkabau karena lahannya yang subur. Jadi lokasi Gunung Marapi ini memiliki pengaruh terhadap orientasi rumah Gadang; yaitu rumah Gadang harus menghadap Gunung Marapi.

\section{Pengaruh Aspek Legenda pada Arsitektur}

Berdasarkan legenda, dahulu kala ada pertentangan antara orang Minangkabau dan orang Jawa. Daripada melibatkan diri dalam perang, kedua orang ini setuju untuk mempertarungkan kerbaunya. Orang Jawa memiliki 
kerbau yang besar, kuat, dan sengit. Sementara itu, orang Minangkabau memiliki anak kerbau yang kecil. Orang Jawa merasa optimis kerbaunya bisa mengalahkan kerbau si Minangkabau. Tetapi orang Minangkabau sangat cerdik. Yang dilakukan oleh orang Minangkabau adalah mereka menjauhkan anak kerbau ini dari induknya dan tidak memberinya makan selama beberapa hari sebelum pertarungan. Sesaat sebelum pertandingan, mereka melampirkan pisau besi yang tajam di ujung tanduknya. Ketika kerbau dan anak kerbau dilepaskan di dalam ring, anak kerbau yang kelaparan mencari susu, melihat kerbau besar dan mengira itu adalah ibunya. Secepatnya anak kerbau berlari ke bawah kerbau mencari susu. Seketika itu juga, pisau yang tajam tadi melukai bagian bawah kerbau. Dia pun terbunuh dan Minangkabau memenangkan pertarungan. Dari sinilah muncul nama Minangkabau, "minang" berarti kemenangan, dan "kabau" berarti karibu atau kerbau air dalam bahasa Minangkabau. Dari legenda tersebut dapat dilihat bahwa tanduk kerbau memiliki arti yang penting dalam masyarakat Minangkabau. Karena itulah bentuk tanduk kerbau ini diabadikan dalam bangunan dan pakaian adatnya.

Legenda Minangkabau tersebut terabadikan dalam arsitektur Minangkabau (rumah Gadang), tepatnya dalam menentukan bentuk atap rumah Gadang yang menjadi ciri khas Minangkabau. Atap rumah Gadang berbentuk bergonjong runcing menjulang, karena itulah rumah Gadang juga biasa disebut sebagau rumah Gonjong atau rumah Bagonjong. Nama ini membedakannya dengan rumah biasa. Lengkungan pada atapnya tajam seperti garis tanduk kerbau (Yurnaldi, 2000: 78)

Gonjong adalah bagian yang paling tinggi dari setiap ujung atap yang menghadap ke atas, dan merupakan ujung turang yang dibalut dengan timah yang berbentuk:
a. 2 labu-labu di bagian bawah
b. 1 belimbing di atas labu-labu
c. 1 anting-anting di atas belimbing
d. 1 ujung yang tajam di atas anting-anting

Antara labu-labu, belimbing dan anting-anting ada peraturan yang searah dengan ujung yang paling atas. Kombinasi bentuk gonjong inilah yang seperti ujung tanduk kerbau jantan, dan dinamakan 'isendak langit'. Turang adalah bagian di bawah gonjong sampai ke batas garis lurus bubungan atas kepemimpinan. Turang ini adalah tempat penahan gonjong. Kombinasi bentuk turang dengan gonjong itulah yang berbentuk 'Rabuang mambacuik'. Keseluruhannya (antara Turang dan Gonjong) disebut Gonjong saja. Bubungan seperti lengkungan 
sayap burung burak akan terbang. Lengkungan bubungan terletak antara dua gonjong yang ditengah. Gonjongnya seperti rebung yang mula keluar dari tanah. Pucuk gonjong mencuat ke atas.

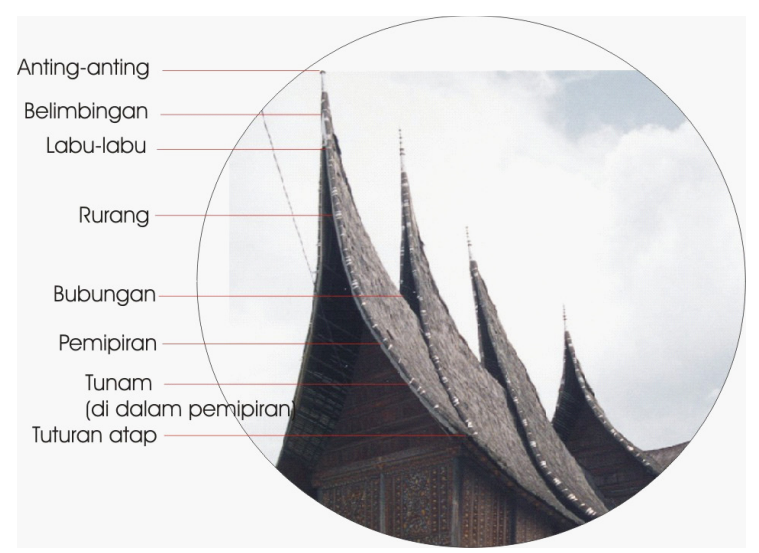

Gambar 1. Nama-nama bagian atap rumah Gadang.

\section{Pengaruh Aspek Letak dan Kondisi Geografis terhadap Arsitektur}

Secara geografis, daerah Minangkabau terletak antara 0054' LU dan 3030' LS serta antara 98 $36^{\prime}$ dan 101053' BT. Kondisi topografi daerah Minangkabau memiliki pengaruh kepada letak lahan atau site didirikannya rumah Gadang. Rumah Gadang tidak boleh didirikan pada tanah yang basah, rendah atau labil, atau di atas lahan pertanian. Hal itu disebabkan karena rumah Gadang tidak memiliki pondasi yang ditanam, sehingga harus diletakkan di tanah yang stabil.

Selain itu kondisi topografi juga berpengaruh terhadap ukuran rumah Gadang. Ukuran rumah Gadang ini disesuaikan dengan ukuran tanah. Tanah yang datar, atau daerah berbukit, atau lembah. Luas rumah Gadang tergantung pada luas lahan datar tempatnya berdiri, tetapi meskipun demikian rumah Gadang tetap memiliki ukuran besaran minimal dan maksimal, yaitu antara tiga sampai sebelas ruang. Bentuk yang dibuat disesuaikan dengan keadaan tanah tersebut. Sehingga diperoleh komposisi yang baik dengan alam lingkungannya. Ukuran lebar sama dengan empat ruangan memanjang yang terdiri dari lima buah tiang, sedangkan ukuran tinggi menurut: "alua jo patuik, raso katinggi diparandah, rasa karandah dipatinggi", maksudnya ukuran-ukuran menurut sepantasnya, kalau ketinggian diperpendek dan sebaliknya, sesuai dengan proporsi yang baik. 
Ukuran panjang rumah Gadang diungkapkan dengan: "Rumah gadang sambilan ruang, salnya kuda balari, sapakiak budak maimbau, sekuat kubin malayang". Ukuran ini relatif, maksudnya ialah (Syamsidar, 1991: 70):

1. Rumah Gadang ada sembilan ruang panjangnya. Satu ruang yaitu jarak antara dua tiang menurut potongan memanjang

2. Ukuran dengan: "salnya kudo balari" artinya, seekor kuda yang berlari kencang dalam satu-satuan waktu yang pendek.

3. "Sapakiak budak maimbau", di mana antara dua ruang yang terjauh masih dapat didengar suara seorang anak yang memanggil

4. "Sekuat kubin malayang", adalah di mana dalam ruang tersebut masih dapat terbang seekor burung kubin (sejenis burung yang dapat terbang cepat), terbang dengan sekencang-kencangnya.

\section{Pengaruh Aspek Iklim terhadap Arsitektur}

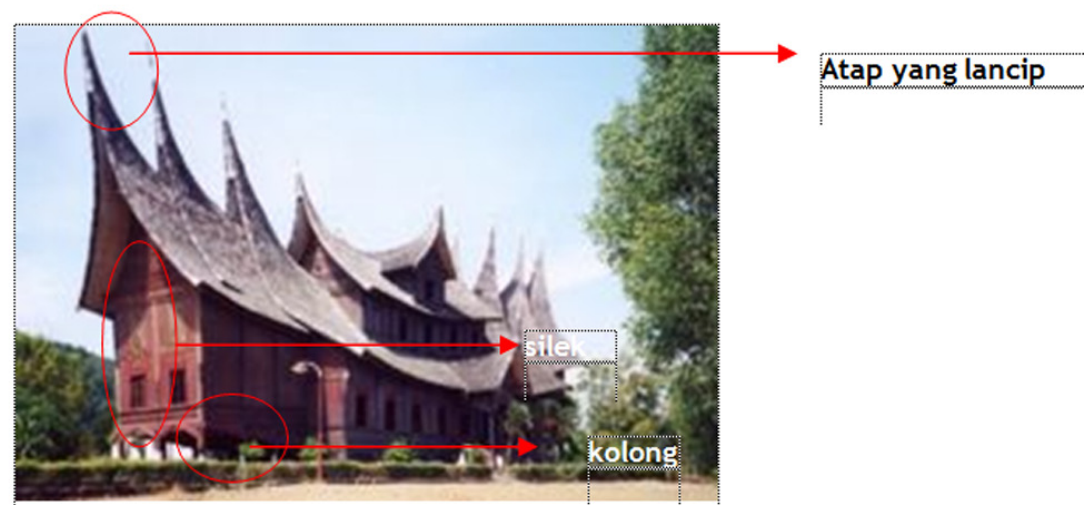

Gambar 2. Bangunan rumah Gadang yang mampu beradaptasi dengan iklim.

Bagian sebelah barat Bukit Barisan dipengaruhi angin laut sepanjang tahun dan beriklim lembab. Keseluruhan daerah ini termasuk lingkungan iklim tropis lembab dengan temperatur antara $22^{\circ} \mathrm{C}$ dan $32^{\circ} \mathrm{C}$ dengan curah hujan $2.289 \mathrm{~mm}$ per tahun. Iklim daerah Minangkabau memiliki pengaruh terhadap bentuk keseluruhan rumah Gadang. Rumah Gadang bisa dikatakan sebagai rumah panggung. Ketinggian panggung atau platform rumah Gadang adalah sekitar satu atau dua meter di atas permukaan tanah. Ruangan di bawah lantai ditutup anyaman bambu untuk kandang. Kolong rumah Gadang tersebut dibuat tinggi untuk memberikan hawa yang segar, terutama pada musim panas. Di samping itu agar lebih aman dalam menghadapi bahaya banjir. 
Bangunan dinding rumah Gadang membesar ke atap yang disebut dengan silek (Pauka, 1997: 35). Ini berguna pada saat musim hujan, mengingat iklim di Indonesia mempunyai curah hujan yang tinggi. Dinding yang berbentuk seperti ini berfungsi untuk membebaskan bangunan dari terpaan air hujan. Atapnya yang lancip berguna untuk membebaskan endapan air pada ijuk yang berlapis-lapis. Air hujan yang bagaimana pun lebatnya, akan meluncur cepat pada atapnya. Selain itu, rumah Gadang relatif tahan terhadap goncangan gempa ataupun angin kencang. Hal ini disebabkan oleh pondasinya yang tidak ditanam ke bumi, serta sambungan kayunya yang sedikit berbeda dengan sambungan pada rumah modern.

\section{Pengaruh Aspek Ekonomi atau Mata Pencaharian terhadap Arsitektur}

Masyarakat Minangkabau memiliki kegiatan perekonomian di bidang pertanian. Hasil pertaniannya antara lain beras sebagai makanan pokok. Selain itu ada pula kayu manis, palem, karet, dan kopi. Selain mahir dalam bertani, masyarakat Minangkabau juga terkenal akan kemampuan bisnisnya, antara lain berdagang. Selain itu mereka juga memiliki keahlian di bidang memahat kayu dan menenun (Minarsih, 1998: 102).

Kegiatan perekonomian masyarakat Minangkabau, memiliki pengaruh terhadap perkampungan masyarakat Minangkabau. Di mana secara umum, pola perkampungannya mengelompok padat di daerah yang dapat dilakukan pertanian dan nelayan.

Perkampungan Minangkabau digolongkan menjadi:

1. Taratak/Lindang

a. Merupakan daerah pertanian di mana orang berladang bersama-sama, bagian yang dikerjakan adalah kepunyaan masing-masing.

b. Tempat tinggal yang diperbolehkan dibangun di daerah ini adalah dangau/rumah dengan tiang empat buah yang terdiri satu ruangan dan belum bergonjong.

c. Letak: jauh dari kampung, belum mempunyai surau.

2. Dusun

a. Merupakan gabungan dari beberapa Taratak atau Taratak yang berkembang (minimal dihuni oleh dua suku)

b. Boleh mendirikan surau tapi tidak boleh mendirikan masjid

c. Rumah boleh bergonjong dua, dan ruangan berderet dua 
3. Koto

a. Gabungan beberapa dusun/dusun yang bekembang (minimal dihuni oleh tiga suku)

b. Dapat mendirikan masjid, balai adat, mempunyai tepian (tempat mandi, tempat mengambil air), perkuburan, dan mempunyai batas dengan Koto lainnya.

c. Rumah bergonjong empat

4. Nagari

a. Mempunyai komunitas koto, dusun, dan taratak

b. Memiliki masjid, balai adat, pasar, tepian, jalan, tanah lapang.

c. Letak bangunan Balai Adat, mesjid yang dilingkungi oleh surau-surau kaum, serta kantor pemerintah Nagari, letaknya berdekatan dengan pasar nagari dan tanah lapang, disebut dengan pusat Nagari/kampung.

d. Pola perkampungan: mengelompok padat, yaitu penduduk bertempat tinggal di pusat nagari, Koto, Dusun. Hanya pada waktu-waktu tertentu pergi ke Taratak. Taratak sebagai daerah perladangan, terpencil dan berfungsi sebagai batas nagari.

e. Nagari terletak di daerah yang dapat dilakukan pertanian dan nelayan; nagari terletak di antara aliran sungai besar dan kecil, di tepi danau, atau di pegunungan

f. Untuk memudahkan komunikasi antar Nagari, dibangun jalan darat. Perkembangan Nagari di pinggir jalan raya sangat pesat.

g. Batas-batas Nagari ditentukan oleh Mana'I, yaitu harta pusaka yang berbentuk tanah yang merupakan hak wilayat.

h. Setiap kaum dalam satu nagari punya tempat pekuburan sendiri

Secara sistem adat tradisional, daerah darat terbagi dalam tiga Luhak (komunitas yang merupakan gabungan beberapa Nagari yang dipimpin oleh Tuan Luhak):
a. Luhak Tanah Datar
b. Luhak Agam
c. Luhak Limapulueh Koto

Keadaan ekonomi juga berpengaruh terhadap layout rumah Gadang. Sesuai dengan mata pencaharian masyarakat Minangkabau, maka dalam layout rumah Gadang terdapat lumbung atau Rangkiang yang berfungsi sebagai tempat penyimpanan makanan. Karena itulah setiap Rumah Gadang memiliki pekarangan, jadi Rumah Gadang tidak berdempet satu sama lain. Di pekarangan itulah 
lumbung-lumbung itu ditempatkan. Lumbung-lumbung tersebut berderet di depan rumah berjumlah minimal tiga. Letaknya ada di ujung kiri pintu masuk, di tengah dekat pintu masuk, dan di ujung kanan pintu masuk. Jumlah lumbung bisa lebih dari tiga tergantung pada keadaan ekonomi pemilik rumah. Bila pemilik rumah adalah keluarga mampu maka akan memiliki lumbung yang lebih dari tiga.

Rangkaian rangkiang atau lumbung yang terletak di depan rumah Gadang memiliki fungsi yang berbeda-beda (Dreyfuss, 1992: 78).

a. Si Tinjau Lauik dengan empat tiang, adalah lambing mamak rumah.

b. Si Bayau-Bayau dengan empat tiang, adalah lumbung tuo tumah atau lumbung pusako, lumbung makanan pagi-petang. Untuk keperluan makan sehari-hari.

c. Si Tangguang Lapa dengan enam tiang adalah lumbung untuk putri, berfungsi sebagai penahan dagang lalu, orang semenda, tempat si miskin selang tenggang, lumbung persiapan musim paceklik datang.

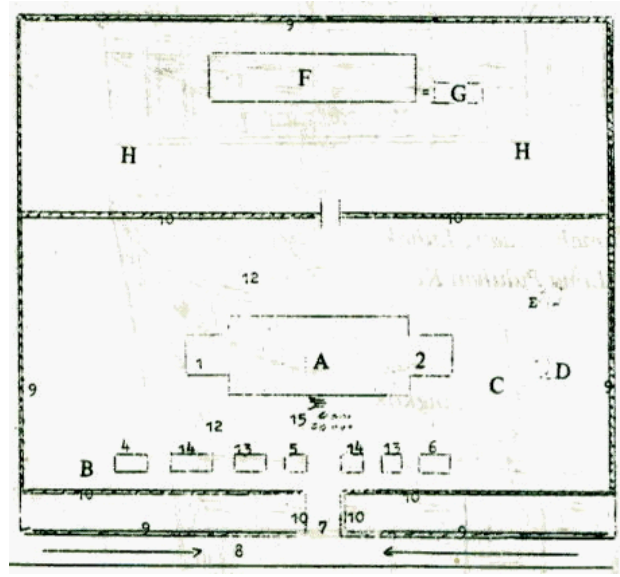

Gambar 3. layout rumah Gadang

Keterangan Gambar:

A: Rumah Gadang

B: Deretan Rangkiang (Lumbung)

C: Lesung

D: Limau Manih Sandaran Alu
1. Anjung Kiri (Ujung)

2. Anjung Kanan (Pangka)

3. Jenjang

4. Sitinjau Lauik

5. Sibayau-Bayau

6. Sitangka Lapa

7. Jalan Masuk

8. Jalan Besar

9. Puding Perak Paga di Luar

10. Puding Emas Paga di Dalam

11. Jalan Kecil Ketapian Mandi

12. Halaman Pakai Pasir Halus

13. Kepuak Gadang

14. Kapuak Ketek

15. Batu Tapakan

E: Kemuniang Hutan Kudo

F: Tebat Ikan

G: Tepian Tempat Mandi

$\mathrm{H}$ : Kebun Bunga

\section{Pengaruh Aspek Sistem Kemasyarakatan terhadap Arsitektur}

Kekerabatan Minangkabau yaitu (Syamsidar, 1991: 81):

a. Tali kerabat mamak kemenakan: anak laki-laki dengan saudara laki-laki ibunya 
b. Tali kerabat suku bako: hubungan serumah gadang (saparuik), sekampung (sesuku), atau sepayung.

c. Tali kerabat induak bako anak pisang: anak dengan saudara perempuan bapaknya

d. Tali kerabat sumando pasumandan: hubungan antara anggota-anggota rumah gadang (paruik) atau kampung dari seorang istri dengan anggota rumah gadang (paruik) atau kampung suaminya.

Masyarakat Minangkabu juga memiliki lapisan Sosial, yaitu (Syamsidar, 1991: 83):

a. Orang Babangso/beradat

b. Orang Inggok mancakam Tabang Manumpu (orang biasa)

c. Anak kemenakan/anak buah (lapisan terendah) atau budak

Secara adat, sistem pemerintahan Minangkabau dibedakan menjadi dua (Syamsidar: 1991: 84).

a. Laras Bodi Caniago: demokrasi, yaitu masyarakat memegang peranan penting

b. Laras Koto Piliang: otokrasi, yaitu dimulai dengan musyawarah tetapi keputusan tetap berada di tangan Penghulu Pucuk atau Penghulu Suku.

Sistem kemasyarakatan memiliki pengaruh terhadap penentuan bentuk rumah Gadang. Sistem pemerintahan yang berbeda dan Luhak yang berbeda memiliki bentuk, ukuran, dan gaya rumah Gadang yang berbeda (Syamsidar, 1991: 89).

1. Gaya kelarasan aliran Koto Piliang: Garudo Tabang (Garuda Terbang)

Di kedua ujung rumah diberi beranjung; sebuah ruangan kecil yang lantainya lebih tinggi dari lantai yang bagian tengah. Mempunyai tempat masuk di bagian tengah badan bangunan pada sisi terpanjang. Pada pesta-pesta adat orang yang terhormat ditempatkan di kiri tempat masuk. Mempunyai ruang tambahan yaitu, anjuang tempat bermain putra-putri. Anjuang ini terletak di kedua ujung dan mempunyai gonjong tersendiri. Pada anjuang deretan tiang paling ujung hanya sebuah yang sampai ke tanah yaitu bagian tengah dalam deretan tersebut. Kamar tidur terletak pada sisi belakang rumah. Kamar yang paling terhormat adalah ujung sebelah kiri pintu masuk.

2. Kelarasan Boni Kaniago: Garudo Manyusukan Anak

Bangunan tidak beanjung, tetapi pada bagian ujung kiri dan kanan 
di bawah gonjong diberi beratap (emper) yang merupakan sayap burung yang sedang mengerami anaknya. Pintu masuk di sisi terpendek bangunan dan kedudukan orang-orang hampir sama. Hanya masih disediakan tempat untuk tamu-tamu dan pemuka adat pada sisi terjauh dari tempat masuk di dekat jendela.

Sedangkan menurut gaya Luhak:

a. Kepunyaan Kaum Penghulu Pucuk di Luhak Tanah Datar: Gajah Maharam model rumah Baanjuang, merupakan aliran Koto Pialang. Mempunyai tangga di depan dan belakang yang letaknya di tengah. Dapur dibangun terpisah pada bagian belakang rumah yang didempet pada dinding.

b. Kepunyaan Kaum Penghulu Andiko di Luhak Agam: Serambi Papek. Kaum Penghulu Andiko di Luhak Agam ini menganut aliran kelarasan bodi caniago. Jadi model rumahnya mirip dengan Kelarasan Bodi Caniago. Letak tangganya di samping sebelah kiri menghadap ke depan. Dapur dibangun terpisah oleh jalan keluar masuk melalui tangga rumah.

c. Luhak Limopuluh Koto : Rojo Babandiang. Bentuk seperti rumah di Luhak Tanah Datar. Pada umumnya Rumah Gadang mempunyai satu tangga yang terletak di bagian depan. Rumah Gadang Rajo Babandiang di Luhak Limopuluhan Kota letak tangganya di belakang. Tangganya terletak pada antara bagian dapur dan rumah.

\section{Pengaruh Aspek Lokasi Site terhadap Arsitektur}

Rumah Gadang memiliki keharusan diletakkan di lahan yang datar. Tetapi lokasi pemilihan site juga tidak boleh sembarangan. Rumah Gadang harus didirikan di tanah pusako tinggi satu paruik, yaitu tanah yang dulunya digarap oleh ninik mereka. Gunanya didirikan di sana adalah rumah itu basis bagi kaum itu untuk bermusyawarah antara mamak dengan kemenakan, tempat mamak memberi petunjuk dan pengajaran kepada anak kemenakannya, tempat anak kemenakan mengadu dan berberita dan juga tempat menyimpan barang-barang pusaka peninggalan mamak-mamak sebelumnya. Jadi rumah Gadang adalah rumah pusako bagi kaum itu.

Lokasi site rumah Gadang memiliki pengaruh kepada jumlah ruangan dan jumlah gonjong. Tempat tinggal yang diperbolehkan dibangun di daerah Taratak adalah dangau/rumah dengan tiang empat buah yang terdiri dari satu ruangan dan belum bergonjong. Sedangkan yang boleh 
dibangun di daerah Koto, adalah rumah yang memiliki gonjong dua dan ruangan berderet dua. Sementara rumah yang dibangun di daerah Dusun sudah boleh bergonjong empat, dan rumah yang dibangun di daerah Nagari boleh memiliki gonjong empat atau lebih (Syamsidar, 1991: 99).

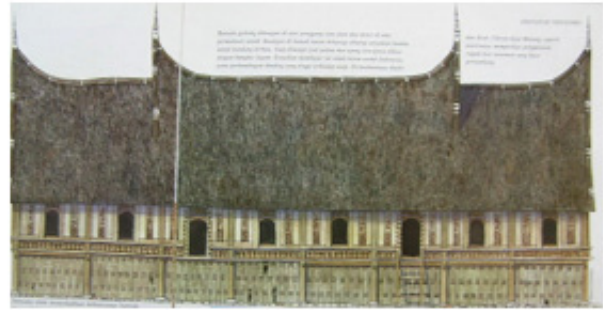

a

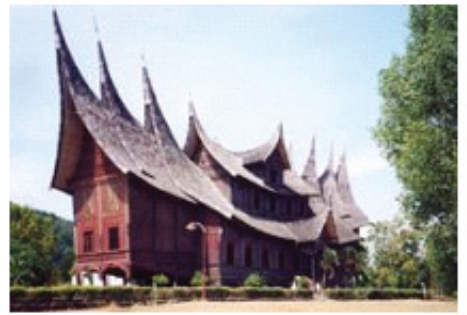

$\mathrm{b}$

Gambar 4. (a) Rumah Gadang bergonjong dan (b) Rumah Gadang bergonjong

\section{Pengaruh Aspek Sosial Budaya terhadap Arsitektur}

Alam merupakan sumber adat dan kepercayaan masyarakat Minangkabau. Peraturan adat berdasar pada alam. Seperti alam, adat juga mengelilingi kehidupan manusia. Dari alam itulah timbul adat matrilineal dalam masyarakat Minangkabau. Adat matrilineal memiliki kesesuaian dengan flora dan fauna di alam yang bisa dilihat bahwa seorang ibulah yang melahirkan generasi selanjutnya dan seorang ibu jugalah yang menyusui anak dan membesarkan anak. Adat Minangkabau, berasal dari alam berdasarkan puisi Alam takambang jadi guru (pertumbuhan alam adalah guru kita). Di alam semua yang lahir ke dunia ini adalah lahir dari ibu, bukan dari ayah. Adat tahu bahwa ibu adalah yang terdekat dengan anaknya dan lebih dominan daripada ayah dalam membentuk karakter generasi selanjutnya. Karena itulah mereka melindungi wanita dan keturunannya karena wanita lebih lemah daripada pria. Mereka berusaha membuat yang lemah menjadi kuat dalam kehidupan manusia. Jika seorang ibu mencampakkan atau tidak mengenali anaknya, adat hadir untuk mengenali garis keturunan anak dan untuk meyakinkan kesejahteraan anak.

Matriarchy bukan soal "female rule", tetapi tentang prinsip dan nilai sosial yang berakar pada makna keibuan di mana kedua jenis kelamin bekerja bersama dan menempati fungsinya masing-masing (Pauka, 1997: 105). Imitasi alam berarti bahwa manusia belajar bukan hanya dari apa yang mendukung kehidupan tapi juga dari apa yang menghancurkannya. Adat mereka adalah mengajari mereka untuk mengambil yang baik dari alam dan membuang yang buruk. Pemeliharaan hukum alam harus diikuti oleh manusia sebagai 
alat peraturan sosial. Selain adat matrilinelal, masyarakat Minangkabau juga memiliki adat mengembara, yaitu pemuda meninggalkan desanya untuk mencari keberuntungan atau pengetahuan selama beberapa tahun sebelum kembali ke desanya. Karena pria Minangkabau sering merantau untuk mencari pengalaman, kekayaan, dan kesuksesan komersial, kelompok keluarga wanita bertanggung jawab untuk memelihara kemenerusan keluarga, distribusi, dan pegolahan lahan. Kelompok ini dipimpin oleh penghulu (pemimpin). Pemimpin dipilih dari kelompok keturunan pemimpin. Posisi penghulu tidak selalu diisi setelah kematian penghulu yang menjabat.

Kekuatan wanita Minangkabau meluas sampai pada dunia ekonomi dan sosial. Wanita mengendalikan tanah warisan dan suami pindah ke rumah istri. Pada upacara pernikahan, istri mengambil suami dari rumahnya dan bersama dengan keluarganya wanita membawa pria ke rumah wanita. Jika terjadi perceraian, pria yang meninggalkan rumah. Kehidupan sosial dan budaya masyarakat Minangkabau memiliki pengaruh pada komposisi massa pada rumah adat Minangkabau. Komposisi massa pada rumah Gadang didasarkan pada sifat-sifat alam dan kebutuhan manusia. Komposisi antara keduanya ini menghasilkan kewibawaan yang dalam. Rumah adat Minangkabau bentuknya simetris, sesuai dengan alam lingkungan yang antara satu dan lainnya terdapat susunan komposisi yang selaras dan seimbang.

Rumah Gadang bentuknya memanjang didasarkan kepada jumlah ruang dalam bilangan yang ganjil, misalnya 3,5,7,9,11 dan ada pula 17 ruang pada masa lalu tetapi sekarang sudah tidak ditemukan lagi (Syamsidar, 1991: 110).

Rumah Gadang secara memanjang dibagi atas beberapa ruang/lanjar. Maka secara melebar ia dibagi kepada didieh. Dan pada sebagian rumah Gadang pada ujung kiri dan kanan ada ruangan yang disebut dengan anjuang dan ada kalanya ada ruangan yang menjorok keluar di atas pintu masuk yang disebut dengan Balai (yang digunakan untuk menerima tamu).

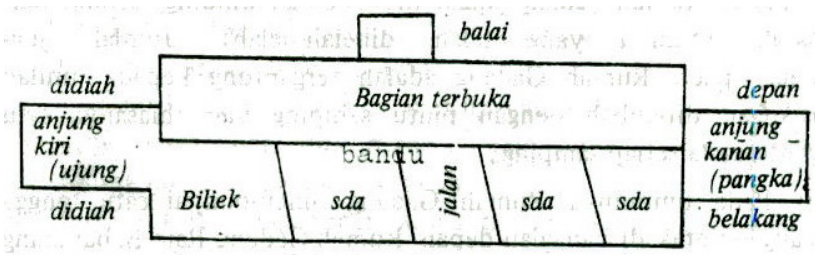

Gambar 5. Komposisi ruang rumah Gadang yang simetris menunjukkan keseimbangan alam (asal adat Minangkabau). Susunan ruangnya juga menunjukkan pola kehidupan sosial. 
Ruangan dalam rumah Gadang dibagi atas beberapa bagian yaitu didieh yang menghadap ke depan atau bagian depan yang merupakan ruang terbuka, dan didieh yang arah ke dalam disebut bandua digunakan sebagai biliek (kamar tidur), dan di tengahnya sebagai tempat sirkulasi keluar masuk. Rumah Gadang terbagi atas bagian-bagian yang masing-masingnya mempunyai fungsi khusus. Seluruh bagian merupakan ruangan lepas kecuali biliek (kamar tidur). Bagian dalam terbagi atas lanjar dan ruang-ruang ditandai oleh tiang.

Lanjar yang terletak pada bagian dinding sebelah belakang yang disebut didieh belakang atau bandua biasanya digunakan untuk kamar-kamar. Jumlah kamar tergantung kepada perempuan yang tinggal di dalamnya atau besarnya lanjar yang ada. Ukuran kamar-kamar ini hanya didesain untuk tidur, karena ukurannya sangat sempit, hanya cukup untuk satu tempat tidur, almari, dan peti penyimpanan. Hal ini mendapat pengaruh dari kehidupan sosial masyarakat Minangkabau yang lebih suka melakukan kegiatan secara bersama daripada individu.

Kamar untuk para gadis ialah pada bagian ujung kanan. Kamar yang di ujung kiri biasanya digunakan oleh penganten baru atau pasangan suami istri yang paling muda. Kalau rumah mempunyai anjuang, maka anjuang sebelah kanan merupakan kamar para gadis. Sedangkan anjuang sebelah kiri digunakan sebagai tempat kehormatan bagi penghulu pada waktu dilangsungkan berbagai upacara adat. Lanjar kedua merupakan bagian yang digunakan sebagai previlasi dari para penghuni kamar. Lanjar ketiga merupakan lanjar tengah pada rumah berlanjar tiga. Sebagai lanjar tengah, ia digunakan untuk tempat menanti tamu dari masing-masing penghuni kamar yang berada di ruang itu. Lanjar tepi, yaitu yang terletak di bagian depan dinding depan. Merupakan lanjar terhormat yang lazimnya digunakan sebagai tempat tamu laki-laki bila diadakan perjamuan (Syamsidar, 1991: 112).

Dari fungsi ruang-ruang tersebut, dapat dilihat bahwa susunan ruangnya menyesuaikan dengan kehidupan sosial, di mana kamar yang merupakan daerah pribadi wanita terletak di belakang, jauh dari jangkauan para pria. Terdapat ruangan tersendiri untuk menerima tamu pria. Hal ini menunjukkan bahwa yang menguasai seluruh ruangan di rumah Gadang adalah kaum wanita. Selain komposisi ruang, ada hal lain yang mendapat pengaruh dari budaya Minangkabau, yaitu ukiran. Setiap rumah Gadang memiliki ukiran pada tiap-tiap bagiannya. Mulai dari tiang, dinding, pintu, jendela, sampai atap. Motif ukiran yang digunakan adalah mengambil dari alam, sesuai dengan asal adat Minangkabau. Motif yang digunakan adalah motif flora dan fauna. Ukiran-ukiran yang diletakkan 
di dinding eksterior berbeda dengan di dinding interior. Terdapat ketentuan tersendiri mengenai hal ini. Tetapi setiap rumah Gadang bebas untuk menentukan flora apa atau fauna apa yang akan digunakan dalam ukiran.

Salah satu hal yang sangat penting pada ukiran rumah adat Minangkabau adalah nama ukirannya. Nama ukiran dapat dilihat dari kaitan ukiran dengan kehidupan masyarakat. Setiap nama ukiran melambangkan suatu gejala hidup dalam masyarakat yang menjadi pedoman dalam penyelenggaraan kehidupan masyarakat Minangkabau. Penggambaran kehidupan gejala alam dapat dilihat dari nama ukiran yang berasal dari nama tumbuh-tumbuhan dan nama binatang. Sedangkan penggambaran nilai-nilai kehidupan manusia dalam masyarakat dapat dilihat dari nama ukiran yang berasal dari kata-kata adat.

Bentuk yang mula-mula timbul adalah bentuk realis, yaitu meniru bentuk alam seperti apa yang dilihatnya. Tetapi kemudian bentuk-bentuk alam itu mulai ada yang dirubah sesuai dengan pandangan dan selera pembuatnya. Tetapi tidak berarti bahwa bentuk realis sudah ditinggalkan sama sekali. Biasanya kedua bentuk itu dikombinasikan dalam sebuah ukiran. Hal itu terlihat menonjol pada ukiran Minangkabau. Pada umumnya motif dasar yang banyak ditiru adalah bentuk tumbuh-tumbuhan dan bentuk binatang. Suatu hal yang menjadi prinsip motif ukiran rumah Minangkabau adalah motif itu diambilkan dari benda-benda mati seperti pemandangan, pasir putih di pantai, gantungan kain dan sebagainya.

Ukiran tidak diletakkan di sembarang tempat. Sebelum ukiran dibuat harus dipikirkan lebih dahulu motif ukiran yang sesuai dengan tempat di mana ukiran itu akan ditempatkan. Umumya orang Minangkabau akan selalu terpancing dengan sifat alam di sekitarnya baik itu merupakan gerak-gerik isyarat ataupun bersifat lambang. Jadi untuk menempatkan suatu ukiran itu hendaknya tepat pada sasarannya (Waterson, 1990: 112).

Ukiran akar-akaran dapat kita temui pada tempat-tempat yang mengundang orang harus terlebih dahulu menggunakan akal pikiran sebelum bertindak, yaitu ditempatkan di tiang-tiang, di pintu gerbang, di pintu masuk di rangkiang. Begitu juga dengan penempatan ukiran yang banyak melambangkan bungabunga. Kebanyakan ukiran bunga-bungaan ini ditempatkan di tempat-tempat yang cepat terpandang seperti di pintu-pintu, jendela-jendela, sampai ke bubungan atap. Ukiran yang bermotif umbi-umbian dan daun-daunan banyak terdapat pada pinggang rumah dan lisplang dalam kamar. Sedangkan untuk ukiran yang bermotif binatang bisa ditempatkan di dalam kamar maupun di luar kamar. Ukiran yang terdapat di dalam kamar adalah yang bermotifkan 
binatang piaraan seperti kucing lalok, kucing menyusukan anak, itiak pulang patang, dan lain-lain. Sedangkan yang bermotif binatang liar kebanyakan di tempatkan di tempat terbuka seperti alang bebega, gajah badorong, kijang lari, ruso balari dalam ransam, harimau dalam parangkok, kudo manyipak, dan lainlain. Untuk ukiran ramo-ramo, kunang-kunang berabah mandi, alang babega, sikumbang janti tantandu bararak, sipaduik manyosok bungo, banyak terlihat pada pintu-pintu kamar anak gadis. Sedangkan pada pintu bujangan banyak dijumpai ukiran paruah anggang, kudo manyipak, takuak kodo manyipak, lokanlokan, kaluang bagayuik, kijang lari, dan lain-lain.

Pada bandua ayam dihiasi dengan tiga jenis ukiran dengan nama aka cino bapilin, siriah gadang, dan sikambang manih. Pada bagian dinding yang lebih luas dihiasi dengan ukiran yang bernama pucuak rabuang, aka cino dan tabendang ka langik. Pada ventilasi di atas jendela dihiasi ukiran dengan nama sikambang manih. Pada ujung atap dihiasi ukiran pisang sasikek, tantadu bararak dan itiak pulang patang. Pada pintu masuk dihiasi ukiran daun bodi, bungo lado, buah palo, pucuak rabuang (Minarsih, 1998: 53).
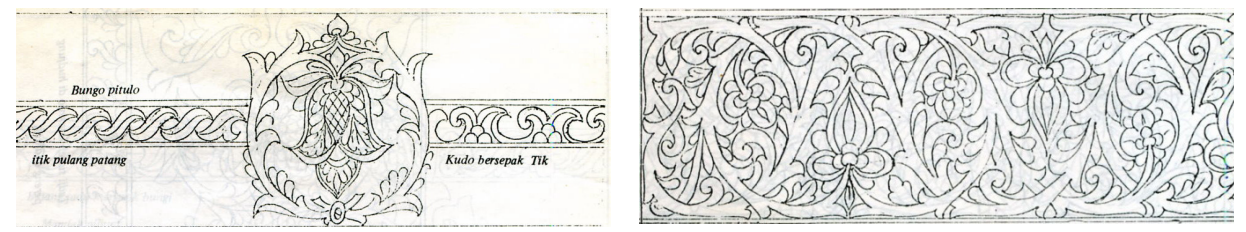

Gambar 6. Ukiran Itik Pulang Patang dan gambar 7: Ukiran Ramo-ramo

Ukiran adat Minangkabau tidak memiliki pola tertentu, sesuai dengan sifat gejala alam yang sukar dibuat polanya. Pola ukiran Minangkabau hanya terletak dalam pikiran dan keahlian masing-masing tukang ukir dalam memindahkan bentuk-bentuk alam ke dalam bentuk-bentuk ukiran. Proses pemindahan bentuk alam ke bentuk ukiran hanya terjadi dengan melihat bentuk alam, kemudian melalui proses abstraksi alam pikirannya, lalu dipahatkan ke atas kayu yang hendak diukir. Dengan demikian cetakan atau pola tetap tidak dikenal dalam ukiran Minangkabau. Di samping itu prinsip pokok dalam ukiran rumah adat Minangkabau disebutkan dalam kata-kata adat yang sudah mentradisi dalam kehidupan masyarakat. Ukiran dalam rumah Gadang tidak dibiarkan polos tanpa warna. Semua warna dipakai untuk menghidupkan seni ukiran. Warna dasar yang digunakan adalah warna merah coklat, dibumbui dengan warna-warna lain yang cocok sehingga tiap ukiran memiliki bentuk yang sesuai dengan kenyataannya. 


\section{Pengaruh Aspek Tradisi Ritual terhadap Arsitektur}

Minangkabau memiliki tradisi mengadakan berbagai macam upacara dan festival, antara lain: 1)Turun mandi - upacara kelahiran bayi. 2) Sunat rasul. 3) Baralek - upacara pernikahan 4) Batagak pangulu (upacara inagurasi pemimpin klan). Pemimpin klan yang lain, semua kerabat pada klan yang sama dan semua orang desa di daerah itu diundang. Upacara akan berlangsung selama 7 hari atau lebih. 5) Turun ka sawah (upacara komunitas pekerja). 6) Manyabik (upacara panen). 7) Hari Rayo. 8) Upacara adopsi. 9) Upacara adat. 10) Upacara pemakaman. 11) Upacara berburu babi hutan liar. 12) Maanta pabukoan (mengirim makanan untuk mertua pada saat Ramadhan). 13) Tabuik (Perayaan muslim pada desa pinggir pantai Pariaman). 14) Tanah Ta Sirah, pelantikan pemimpin klan baru (Datuk) ketika yang lama meninggal dalam beberapa jam. (tidak perlu melapor pada batagak pangulu, tapi klan harus mengundang semua pemimpin klan di daerah tersebut). 15) Mambangkik Batang Tarandam, pelantikan pemimpin klan baru (Datuk) ketika yang lama meninggal dalam 10 sampai 50 tahun atau lebih. (harus ada batagak pangulu).

Berbagai macam upacara adat yang diselenggarakan di Minangkabau tersebut memiliki pengaruh terhadap arsitektur rumah Gadang dan juga permukimannya. Pada rumah Gadang pengaruhnya adalah terletak pada susunan ruangnya. Rumah Gadang memiliki bagian yang terbuka untuk penyelenggaraan upacara adat, selain itu terdapat ruangan khusus bagi penghulu pada waktu upacara adat, yaitu anjuang sebelah kiri. Sedangkan pengaruhnya terhadap permukiman yaitu terdapatnya tanah lapang di pusat nagari tempat diselenggarakannya upacara-upacara adat.

\section{Pengaruh Aspek Keluarga terhadap Arsitektur}

Masyarakat Minangkabau memiliki sistem kekeluargaan matrilineal, seorang anak dianggap sebagai keturunan dari ibunya, bukan ayahnya. Seorang anak lelaki, memiliki tanggung jawab utama terhadap klan ibu dan saudara wanitanya. Dalam pelaksanaannya, pada kebanyakan desa seorang pemuda akan mengunjungi istrinya di sore hari tapi menghabiskan hariharinya dengan saudara perempuannya dan anak-anaknya. Hal yang biasa bagi saudara perempuan yang telah menikah untuk tetap berada di rumah orang tuanya. Seorang anak lelaki yang sudah remaja, sudah tidak memiliki tempat lagi di rumah orang tuanya. Biasanya mereka keluar dari rumah dan tidur di surau bersama pemuda-pemuda lain sampai dia dijemput oleh wanita yang melamarnya. Jadi hanya anak wanita yang tetap tinggal di rumah ibunya. Yang 
tinggal di rumah adalah satu garis keturunan anak-ibu-nenek. (Kosty, 2002: 45).

Aspek keluarga memiliki pengaruh yang besar terhadap jumlah dan susunan ruang pada rumah Gadang. Rumah Gadang pada umumya terdiri dari tiga ruang sampai sebelas ruang, tergantung dari jumlah wanita yang ada di rumah tersebut. Tetapi rumah Gadang ini bukan rumah tumbuh. Rumahnya sudah dedesain untuk ditempati oleh tiga generasi, anak-ibu-nenek, dengan jumlah ruang maksimal 11 ruang. Bila anggota keluarga wanita bertambah sampai ruang yang ada sudah tidak cukup lagi, maka dibangunkan rumah yang baru.

Hirarki dalam rumah Gadang berdasarkan pada siklus kehidupan wanita, dan membentuk perjalanan dari pusat menuju ke anjuang, kemudian biliak, dan terakhir dapur Anjuang merupakan tempat tinggal banyak anak perempuan yang baru menikah dan suaminya tinggal. Wanita lain yang sudah menikah dan pasangannya menempati bilik atau biliak, di belakang rumah. Setiap gadis yang menikah pindah ke anjuang, sementara wanita yang sudah menikah lainnya pindah bergeser satu ruangan ke arah dapur. Idealnya, wanita tertua di rumah harus tidur di biliak sebelah dapur. Jika tidak ada biliak kosong untuk ditempati, ia pindah ke ruangan yang disebut pangkalan (tiang pusat) melambangkan kedudukannya sebagai wanita tua (Tjahjono, 2002: 63).

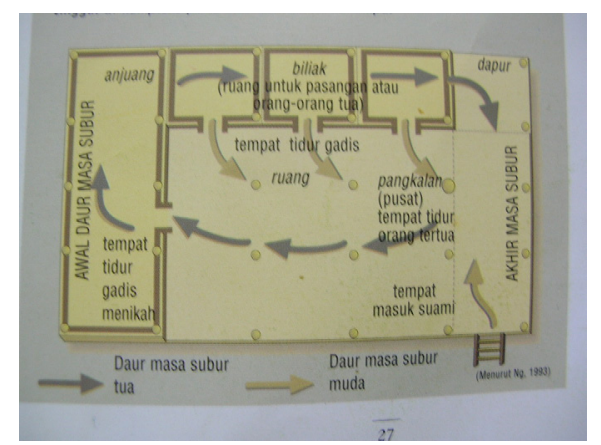

Gambar 8. Hirarki rumah Gadang berdasarkan siklus kehidupan wanita

\section{Pengaruh Aspek Material yang Tersedia terhadap Arsitektur}

Material yang tersedia di daerah Minangkabau adalah jenis kayu-kayuan yang ditemui di hutan, antara lain meranti, kayu kalek, balam, paniang-paniang, banio, bapati, kemenyan, rotan, manau, surian, razak. Selain itu juga terdapat bambu dan ijuk. Material yang tersedia tersebut memiliki pengaruh pada material yang digunakan pada rumah Gadang. Pada rumah Gadang yang asli, 
lantai tidak terbuat dari kayu, akan tetapi dibuat dari bambu yang dipecah dan didatarkan yang disebut dengan palupuah. Jadi tidak menggunakan paku di dalam pemasangannya tetapi hanya menggunakan rotan yang telah dibelah untuk mengikat sehingga lantai tersebut tidak terlepas dan bercerai berai.

Tiang atau kolom terbuat dari kayu yang kuat. Untuk sandi atau pondasi menggunakan batu yang permukaannya datar. Atap terbuat dari ijuk. Saga ijuk diatur susunannya dengan nama Labah Mangirok atau Labah Maraok dan Bada Mudiak. Sedangkan loteng merupakan ruangan antara lantai dan atap bangunan, biasanya terbuat dari kayu atau papan yang tidak datar. Terbatasnya material yang tersedia tersebut, akan memiliki pengaruh terhadap teknik pembangunannya, serta struktur dan konstruksinya, lihat gambar 9 .

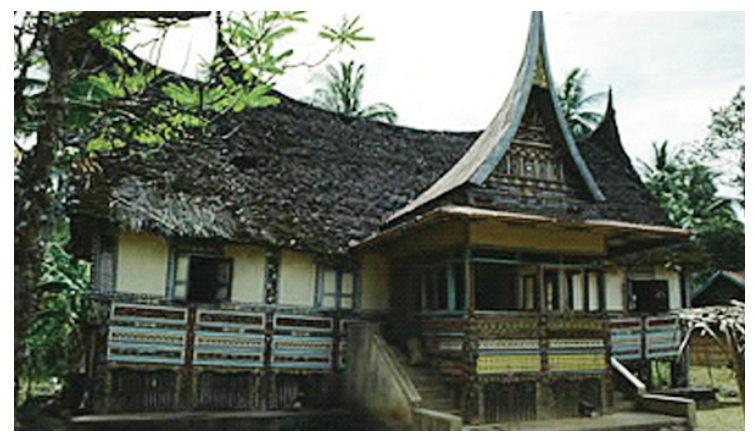

Gambar 9. Rumah Gadang yang memiliki material batu pada pondasinya, kayu pada tiangnya, dan ijuk pada atapnya.

\section{Pengaruh Aspek Agama terhadap Arsitektur}

"Menjadi Minang adalah menjadi Muslim" merupakan suatu kalimat dari pepatah masyarakat Minangkabau. Hampir 100\% masyarakat Minangkabau memeluk agam Islam. Memang budaya masyarakat Minangkabau diawali oleh adat berabad-abad lalu. Tapi kemudian Islam datang, dibawa oleh pedagang di daerah pesisir, antara abad ke-14 dan ke-16. Kemudian kebudayaan Minangkabau dan Islam hidup berdampingan karena pada dasarnya banyak ajaran adat Minangkabau yang sesuai dengan ajaran Islam.

Pengaruh Islam terlihat pada beberapa aspek penyusun arsitektur tradisional Minangkabau. Salah satunya adalah pada aspek iklim. Rumah Gadang memiliki desain yang mampu beradaptasi dengan iklim. Hal ini memungkinkan rumah Gadang memiliki kenyamanan termal, sehingga menyebabkan orang yang tinggal di dalamnya tidak perlu menggunakan alat-alat khusus untuk memodifikasi iklim, seperti AC. Hal ini menunjukkan bahwa rumah Gadang 
termasuk rumah yang hemat energi. Aspek ini merupakan salah satu nilai Islam yang terkandung di rumah Gadang. Dengan menghemat energi, berarti masyarakat Minangkabau ikut memelihara alam.

Aspek berikutnya yang sesuai dengan nilai Islam adalah aspek sosial budaya. Hal ini memiliki pengaruh pada susunan ruang rumah Gadang. Susunan ruang di Rumah Gadang memiliki pemisahan yang jelas antara pria dan wanita. Sebagaimana layaknya ajaran Islam yang melarang pria dan wanita yang bukan muhrim untuk berdekatan. Susunan ruang di dalam rumah gadang dirancang khusus untuk wanita. Budaya Minangkabau yang memuliakan wanita ini, juga sesuai dengan nilai Islam, dimana setiap manusia harus menghormati wanita terutama ibu. Bukan hanya susunan ruang, pemilihan dekorasi pun tidak bertentangan dengan ajaran Islam. Ukiran-ukiran yang berasal dari bentuk flora dan fauna diolah sedemikian rupa, sehingga menghasilkan bentuk yang rumit yang jauh dari bentuk asli flora dan fauna yang digunakan.

Aspek material yang tersedia juga sesuai dengan nilai alam. Masyarakat Minangkabau memanfaatkan alam yang sudah disediakan oleh Allah SWT untuk menciptakan rumah tinggal mereka. Dalam hal ini mereka juga menghemat energi dalam pendirian bangunannya. Dengan menggunakan bahan lokal, mereka tidak perlu menggunakan energi untuk pengiriman material. Selain itu desain bangunannya juga lebih menyatu dengan alam. Islam juga memiliki pengaruh terhadap pola permukiman. Di setiap Dusun terdapat surau, dan di setiap Koto dan Nagari terdapat masjid yang digunakan sebagai tempat beribadah umat Islam. Letak masjid ini berada di pusat sehingga mudah dijangkau oleh semua penduduk.

\section{Simpulan}

Terbentuknya arsitektur vernakular Minangkabau tidak lepas dari aspek-aspek yang mempengaruhi arsitektur vernakular pada umumnya. Karena arsitektur vernakular bisa dikatakan sebagai arsitektur rakyat, maka terbentuknya arsitektur vernakular tersebut akan dipengaruhi oleh kehidupan masyarakat dan lingkungannya. Dari pembahasan aspek-aspek yang mempengaruhi arsitektur tradisional Minangkabau di atas, maka dapat disimpulkan pengaruh aspek-aspek kehidupan terhadap arsitektur Minangkabau dapat dilihat pada tabel sebagai berikut: 
Tabel 1. Pengaruh aspek-aspek kehidupan terhadap arsitektur Minangkabau

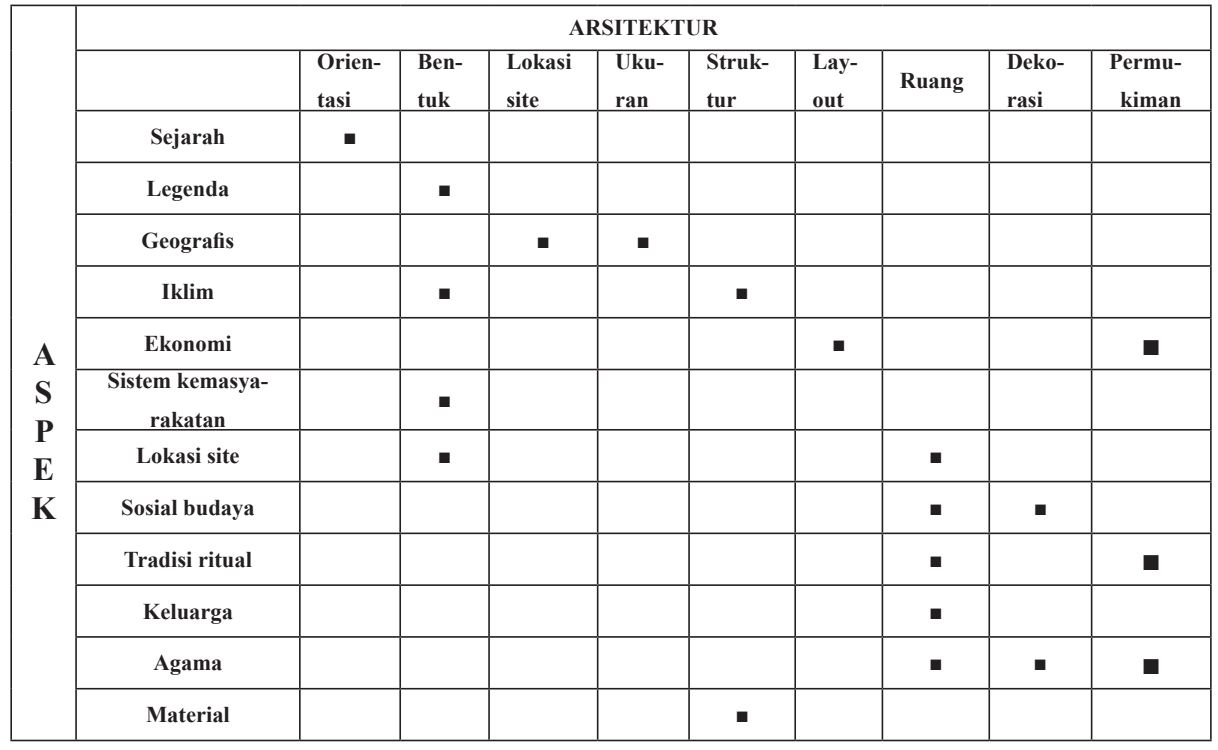

\section{Daftar Pustaka}

Dreyfuss, Hermine L. 1992. A traditional Minangkabau rice-storage building, Sumatra. www.photius.com. [15 Maret 2007].

Kosty, Pam. 2002. Indonesia's matriarchal Minangkabau offer an alternative social system. www.sas.upenn.edu. [5 Maret 2007].

Minarsih. 1998. Korelasi Antara Motif Hias Songket Dan Ukiran Kayu Di Propinsi Sumatera Barat (Studi Kasus Daerah Pandai Sikek, Silungkang Dan Kubang). digilib.itb.ac.id. [15 Maret 2007].

Papanek, Victor. 1995. The Green Imperative: Ecology and Ethics in Design and Architecture. London: Thames and Hudson.

Pauka, Kirstin, 1997. Silek, The Martial Arts of the Minangkabau in West Sumatra. Journal of Asian Martial Arts. Volume 6, Issue 1: 62-79.

Prijotomo, Josef. 2004. Arsitektur Nusantara Menuju Keniscayaan. Surabaya: Wastu Lanas Grafika.

Syamsidar, B.A. 1991. Arsitektur Tradisional Daerah Sumatra Barat. Jakarta: 
Departemen Pendidikan dan Kebudayaan.

Tjahjono, Gunawan. 2002. Indonesian Heritage, Arsitektur. Jakarta: Buku Antara Bangsa

Waterson, Roxana. 1990. The Living House: An Anthropology of Architecture in South East Asia. Oxford: Oxford University Press.

Yurnaldi, 2000. Bagonjong, Wujud Arsitektur dari Karya Sastra. www.kompas. com. [15 Maret 2007]. 